\title{
Woody biomass: its use and a viable mitigation option for carbon capture and storage
}

\author{
Keith Openshaw \\ 2430 Shenandoah St., Vienna Virginia 22180, USA. Tel. (1) 7038765306 \\ Corresponding Author email: kopenshaw@cox.net
}

\begin{abstract}
The recent IPCC Fifth Assessment Report (AR5) on climate change, states that to avoid a $2^{\circ} \mathrm{C}$ rise in average global surface temperature warming above pre-industrial levels, concerted action needs to be taken. But because of stunning government inaction to deal with climate change, the 'symbolic doomsday clock' has recently been moved forward by two minutes to three minutes to midnight. One of the recommendations of the AR5 report is to greatly expand carbon capture and storage (CCS), but only specific 'high tech' solutions were considered. A 'low tech' solution, which is universal, is CCS and use through tree planting. From 2016 to 2050 about $420 \mathrm{GtC}$ will have been added to the atmosphere. Models were compiled to examine the land requirements and the probable cost involved in capturing this carbon in wood and forest soils. The most optimistic model estimates that 109 million hectares (ha) of farmland converted to plantations woodlots and agro-forestry etc. is sufficient to capture $420 \mathrm{GtC}$ at a cost of US $\$ 272$ billion $\left(0.18 / \mathrm{CO}_{2}\right)$ : an obvious candidate for the 'green climate fund'. The most pessimistic model would require 331.5 million at a cost of US\$1,243 billion $\left(0.81 / \mathrm{tCO}_{2}\right)$. It is proposed that two-thirds of the planting take place in less developed countries (LDCs) to provide employment and wood products, especially for the rural poor. Because population increase is a prime cause of deforestation, loss of biodiversity and the expanded use of natural resources, tempering population increase is vital as is increasing agricultural (and silvicultural) productivity. CCS through tree planting/tending and forest/woodland management should assist many people, especially the rural poor in LDCS, and be an essential part in the quest for greenhouse gas mitigation and truly sustainable development.
\end{abstract}

Key words: Global warming; CCS; Plantations/forest management; Wood use; Renewable energy; Tempering population increase; Poverty alleviation; Agricultural productivity; Sustainable development.

\section{INTRODUCTION}

Over the last 130 years of record keeping, 2014 was the hottest on record and nine of the 10 hottest recorded years have occurred since 2000! Because of climate change inaction the 'symbolic doomsday clock' was moved forward by two minutes (in January 2015) to three minutes to midnight. The last previous adjustment move was made in 2012 when it was moved forward by one minute, again because of climate change inaction. Practically all climate scientists and climate diplomats agree that to avoid catastrophic damage to the earth biosphere, which may spell doom for Homo sapiens, global temperatures should not rise by more than $2^{\circ} \mathrm{C}$ compared to pre-industrial levels. The recent IPCC Fifth Assessment Report (AR5) on climate change (IPCC:
AR5. 2014), indicates that to curtail the rise in global warming by $2^{0} \mathrm{C}$, concerted action has to be taken to: temper the burning of fossil fuels; substantially increase energy efficiency measures; greatly expand the use of renewable energy; and accelerate carbon capture and storage. AR5 postulates that if sufficient measures are not taken, then it will be impossible to hold the temperature increase to $2^{\circ} \mathrm{C}$ by 2030 .

Climate talks were held in Lima, Peru to from 1-12 December 2014 to agree on a draft, legally binding climate change treaty, which will be presented to all parties in Paris in December 2015. By March 2015, participating countries agreed to propose commitments to cut emissions from 2020 onwards. The Lima talks also 
have to find ways to increase the 'Green Climate Fund' to meet a target budget of $\$ 100$ billion $\left(\$ 10^{9}\right)$ per year (The Economist, $6^{\text {th }}$ December 2014). It is agreed that the main causes of the accumulation of atmospheric greenhouse gases (GHG) are emissions of $\mathrm{CO}_{2}$ from fossil fuel burning and land use changes as well as methane production and emissions from plants, animals and fossil fuels. It is difficult, both economically and practically, to reduce the consumption of fossil fuels in the short run. Indeed the International Energy Agency (IEA) forecast that coal and oil consumption will only plateau by 2040 and natural gas use will still be increasing. The average total annual emissions from fossil fuels may reach $12 \mathrm{GtC}$ by $2050\left(44 \mathrm{GtCO}_{2}\right.$ ) (IEA 2014), for a 35 year total of $420 \mathrm{GtC}$. Yet many scientists suggest that the greatest danger to curtail global warming lies in the failure of leaders to act on climate change. According to Kennette Bennedict, the Executive Director of the Bulletin of the Atomic Scientists, "Stunning government failures have imperilled civilisations on a global scale. World leaders have failed to act on a scale or at a speed to protect humanity from catastrophe." (The Guardian Weekly $30^{\text {th }}$ Jan. 2015).

\section{Carbon Capture and Storage}

Economic development and population increase are the two principal factors driving the increased use of fossil fuels and land use changes, especially deforestation. IPPC AR5 lays great store in a massive increase in carbon capture and storage (CCS). At present carbon sequestration is a priority for many (industrialized) countries. However, only 'high tech' CCS solutions are being considered, such as capturing $\mathrm{CO}_{2}$ emissions from refineries, power stations, combined heat and power (CHP) units or cement factories. The approach entails capturing and condensing $\mathrm{CO}_{2}$ from such plants and sequestering it in leak-proof areas below ground or below the sea. Governments such as the USA and the UK have offered up to one billion dollars or more to provide commercial options for CCS, but they are still in the experimental stage.

One CCS proposal outlined by Bryant (2013) describes the capture of $\mathrm{CO}_{2}$ from power stations and sequestering it under high pressure into brine aquifers 3 $\mathrm{km}$ below the sea surface. Under high pressure this would force deep hot brine containing methane, to rise. When the pressure is reduced at the surface some of the methane will dissolve out of the solution and can be used for various purposes, especially to substitute coal and oil. The heat is captured from the remaining hot brine and it is then returned to the brine aquifer. No costs are given for this proposal.

Such CCS options are site-specific and do nothing to capture $\mathrm{CO}_{2}$ emissions from vehicles, homes, small fossil-fuel burning plants and land clearing operations.
However, there is a 'low tech' solution that can capture $\mathrm{CO}_{2}$ emissions from all sources and is relatively cheap. This solution entails capturing $\mathrm{CO}_{2}$ in perennial plants, principally trees. Capturing atmospheric $\mathrm{CO}_{2}$ in this way, especially in woody biomass, not only sequesters $C$ in wood, but also increases the $C$ content in the soil beneath the trees. As well as sequestration carbon, it also gives an annual yield of renewable carbon in the form of woody biomass that can be used for energy, converted into organic compounds or stored in wood products such as building materials, joinery and furniture. This can be done worldwide through improving existing forests, woodlands, grasslands and arable systems, and especially with plantations, woodlots and on-farm approaches using appropriate improved growing stock. It is also a way to enhance economic development, especially for the rural poor in less developed countries.

\section{Global Warming and Biomass Fuels}

Unlike fossil fuels, biomass fuels are more or less GHG benign if they come from a sustainable supply. This is because the emission of carbon dioxide would have occurred through decomposition, wild fires or respiration if the biomass was not used for energy or other purposes. Every year, land and sea plants absorb about 100 giga tonnes $\left(10^{9} \mathrm{t}\right)$ of atmospheric carbon $\left(367 \mathrm{Gt} \mathrm{CO}_{2}\right)$ and an equal quantity is returned to the atmosphere through respiration, decay and burning (Hall \& Rao, 1994). Over half of this total is from land plants. Each year, only about $1.4 \mathrm{Gt}$ of this carbon from land plants $\left(5.1 \mathrm{Gt} \mathrm{CO}_{2}\right)$ is used for energy purposes, whereas about $9 \mathrm{GtC}$, (33 $\mathrm{GtCO}_{2}$ ) is emitted to the atmosphere through the burning of fossil fuels. It is this fossil fuel burning that is the main cause of atmospheric $\mathrm{CO}_{2}$ accumulation, now about 400 parts per million (ppm) and increasing annually at an estimated $2 \mathrm{ppm}$. The pre-industrial level of atmospheric $\mathrm{CO}_{2}$ was about $280 \mathrm{ppm}$. One way to reduce this accumulation is to use more of the potentially available biomass in land plants (FAO 2010a), estimated to be 50 Gt per year of carbon equivalent $\left(183 \mathrm{GtCO}_{2}\right)$, (Hall \& Rao, 1994) about eight times the annual quantity of carbon given off by fossil fuels. According to BernersLee and Clark (2013), "We can't burn half the world's oil, coal and gas. So how do we quit?" They propose a number of solutions such as reducing subsidies for fossil fuels, curtailing fossil fuel exploration, introducing or expanding a carbon tax on fossil fuels, increasing renewable energy efficiency and consumption, capturing and using more methane from plants, animals and fossil fuels and sequestering more atmospheric carbon. In the authors' opinion, at least five other interventions are required, namely: tempering population increase, especially in Africa; improving (rural) health facilities; increasing agricultural productivity for subsistence and cash agriculture; increasing forest/tree productivity; and improving (rural) infrastructure. 
Table 1. Area required to sequestrate $420 \mathrm{Gt}$ of atmospheric carbon in wood and soils and the total removals of wood by 2050 together with the projected annual capture and removals from 2050 onwards.

\begin{tabular}{|c|c|c|c|c|c|c|c|c|}
\hline \multicolumn{2}{|c|}{ Rotation period } & \multirow{3}{*}{$\begin{array}{c}\text { Area to } \\
\text { capture } \\
420 \times 10^{9} \\
\text { tC by } \\
2050\end{array}$} & \multicolumn{3}{|c|}{ Total wood removals 2022 to 2050} & \multicolumn{3}{|c|}{ Annual capture/removals after 2050} \\
\hline \multirow{2}{*}{$\begin{array}{c}\text { Tropical } \\
\text { plantations }\end{array}$} & \multirow{2}{*}{$\begin{array}{l}\text { Temperate } \\
\text { plantations }\end{array}$} & & \multirow[t]{2}{*}{ Carbon } & \multirow[t]{2}{*}{ Volume } & \multirow{2}{*}{$\begin{array}{l}\text { Energy: } \\
\text { low heat } \\
\text { value }\end{array}$} & \multirow{2}{*}{$\begin{array}{c}\text { Carbon } \\
\text { capture } \\
\text { (net) }\end{array}$} & Removals & Energy \\
\hline & & & & & & & Volume & $\begin{array}{c}\text { Iow heat } \\
\text { value }\end{array}$ \\
\hline Years & years & million ha & $10^{9} \mathrm{tC}$ & $10^{9} \mathrm{~m}^{3}$ & EJ & $10^{9} \mathrm{tC}$ & $10^{9} \mathrm{~m}^{3}$ & EJ \\
\hline 01035 & 35 & 109.0 & 20.53 & 70.52 & 776 & 15.20 & 3.41 & 38 \\
\hline P 1035 & 35 & 163.5 & 20.53 & 70.52 & 776 & 15.20 & 3.41 & 38 \\
\hline 0735 & 35 & 115.5 & 21.52 & 74.00 & 814 & 15.32 & 3.61 & 40 \\
\hline P 735 & 35 & 173.2 & 21.52 & 74.00 & 814 & 15.32 & 3.61 & 40 \\
\hline O 1010 & 35 & 178.5 & 39.40 & 153.18 & 1,685 & 14.74 & 5.58 & 61 \\
\hline P 1010 & 35 & 267.8 & 39.40 & 135.18 & 1,685 & 14.74 & 5.58 & 61 \\
\hline O 77 & 35 & 221.0 & 47.88 & 164.57 & 1,810 & 15.32 & 6.91 & 76 \\
\hline $\mathrm{P} 77$ & 35 & 331.5 & 47.88 & 164.57 & 1,810 & 15.32 & 6.91 & 76 \\
\hline
\end{tabular}

Note. $\mathrm{O}=$ optimistic assumptions. $\mathrm{P}=$ pessimistic assumptions. Assume $1.7 \mathrm{~m}^{3}=1 \mathrm{t}$ dry wood. Ash content $1 \%$. Ash free wood contains $50 \% \mathrm{C}, 6 \% \mathrm{H}, 44 \% \mathrm{O}$. Carbon capture is net (gross capture minus removals), Values have been rounded. $\mathrm{EJ}=10^{18} \mathrm{~J} .11 \mathrm{GJ}=1 \mathrm{~m}^{3}$. Detailed calculations are given in Annex 1. Trees on rotations of 7 and 10 years are not thinned, just felled.

A follow-on publication by Barnham (2014) proposes that solar power, especially solar photo-voltaic (PV) is the principal solution for reducing the consumption of fossil fuels. While solar PV could be a useful tool in industrialized countries, because of costs and maintenance it is only partially relevant in developing countries and other options have to be considered to offset the rapidly increasing use of fossil fuels.

At stated above, according to the latest IEA figures, about $9 \mathrm{Gt} / \mathrm{yr}$. of carbon $\left(33 \mathrm{GtCO}_{2}\right)$ are emitted to the atmosphere by burning fossil fuels: this could increase to about $12 \mathrm{Gt} / \mathrm{yr}$ by 2050, even with energy efficiency measures and increased use of renewable energy (IPCC, 2014). Also today, deforestation, caused by land use changes results in about $1.4 \mathrm{GtC}$ being emitted each year; this may drop to about $1.0 \mathrm{GtC} / \mathrm{yr}$ by 2050 . What would it take to capture all this carbon in woody biomass and forest/plantation soils? On average about $12 \mathrm{Gt}$ of carbon would have to be sequestrated each year in wood and soil from 2016 to 2050 to achieve a total of $420 \mathrm{GtC}$. This is a very bold measure that governments should seriously consider. It would entail the cooperation of millions of people, not just the few, but it would give these millions of (mostly rural) people a stake in their own progress and ensure sustainable development without endangering the planet.

\section{Carbon Capture and Storage with Biomass}

Biomass production depends on the plant species together with precipitation and ground water availability, including irrigation. Two options are proposed - one optimistic and the other pessimistic. Simple models have been constructed which assume that plantation trees either cloned or from superior seeds from tree breeding will be planted in areas with the equivalent precipitation of 1,000 to $1,500 \mathrm{~mm}$ per year.

In tropical/sub-tropical areas for the optimistic assumption, it is assumed that the trees will grow at an average annual rate of $30 \mathrm{~m}^{3} / \mathrm{ha}$. In Brazil it has been reported that some Eucalyptus species are growing at an average rate of $45 \mathrm{~m}^{3} /$ ha/year, (FAO 2000). This is the growth of stem wood to $7 \mathrm{~cm}$ top diameter (t.d.). In addition, there will be about $7.5 \mathrm{~m}^{3} / \mathrm{ha}$ of branch wood and tops (25\% more of above-ground woody biomass) and at least $9.4 \mathrm{~m}^{3} / \mathrm{ha}$ of root wood $(25 \%$ more than above-ground woody biomass (Pan, et al 2000), for a total of $46.9 \mathrm{~m}^{3} / \mathrm{ha} / \mathrm{yr}$. Assuming that $1.7 \mathrm{~m}^{3}=1$ dry tonne This is the assumed average between conifers $\left(1.85 \mathrm{~m}^{3}=\right.$ 1 dry tonne) and hardwood $\left(1.65 \mathrm{~m}^{3}=1 \mathrm{t}\right.$.), with $25 \%$ being conifers., then $46.9 \mathrm{~m}^{3}=27.6 \mathrm{t}$ wood containing 13.65 t C (1\% ash content and $50 \%$ carbon). The average annual increase in soil carbon under such tree growth is an estimated $0.82 \mathrm{tC} / \mathrm{ha}$, (Silver, et al 2000) bringing the total carbon sequestration to be $14.47 \mathrm{tC} / \mathrm{yr}$.

In temperate areas, the average stem growth rate to 7 $\mathrm{cm}$ t.d. is assumed to be $15 \mathrm{~m}^{3} / \mathrm{ha} / \mathrm{yr}$ and the average total annual carbon sequestration in wood and soil would be half the tropical rate, i.e. $7.23 \mathrm{tC} / \mathrm{yr}$. This carbon accumulates over time. It is assumed that two-thirds of the planting takes place in tropical countries and onethird in temperate countries. The pessimistic or conservative growth rate is $20 \mathrm{~m}^{3} / \mathrm{ha}$ in tropical countries and $10 \mathrm{~m}^{3} / \mathrm{ha}$ in temperate countries.

Models have been compiled assuming rotation ages in the tropics of 7, 10 and 35 years. In temperate areas only one rotation age has been chosen, namely 35 years, (Annex 1). In most models the planting is phased over 10 years, except for the 7 year rotation when the planting is phased over 14 years. Using the above information, the accumulation of carbon for the various models was calculated for the period 2016 to 2050 . This is the assumed average between conifers $\left(1.85 \mathrm{~m}^{3}=1\right.$ dry tonne) and hardwood $\left(1.65 \mathrm{~m}^{3}=1 \mathrm{t}\right.$.), with $25 \%$ being conifers.Knowing the average accumulation of carbon on one hectare over the 35-year period, an estimate can be made of the plantation area required to capture $420 \mathrm{GtC}$ by 2050 . This is shown in Table 1 , together with removals 
Table 2. Capital and total costs in US\$ for the models given in Table 1 to sequester $420 \mathrm{Gt}$ of atmospheric carbon by 2050 in plantation wood and forest soils.

\begin{tabular}{|c|c|c|c|c|c|c|c|c|}
\hline \multicolumn{2}{|c|}{ Rotation period } & \multirow{2}{*}{$\begin{array}{l}\text { Area to } \\
\text { capture } \\
420 \mathrm{GtC}\end{array}$} & \multicolumn{2}{|c|}{ Total capital costs } & \multicolumn{2}{|c|}{ Total cost $(+25 \%)$} & \multicolumn{2}{|c|}{$\begin{array}{c}\text { Cost per tonne } \\
\text { carbon }\end{array}$} \\
\hline $\begin{array}{c}\text { Tropical } \\
\text { plantations }\end{array}$ & $\begin{array}{l}\text { Temperate } \\
\text { plantations }\end{array}$ & & Low & High & Low & High & Low & High \\
\hline Years & years & million ha & $\begin{array}{c}\text { \$ billion } \\
\text { (rounded) }\end{array}$ & \$ billion & \$ billion & $\$$ billion & $\$$ & $\$$ \\
\hline 01035 & 35 & 109.0 & 218 & 327 & 272 & 409 & 0.65 & 0.97 \\
\hline P $10 \quad 35$ & 35 & 163.5 & 327 & 490 & 409 & 613 & 0.97 & 1.46 \\
\hline O 735 & 35 & 115.5 & 231 & 346 & 289 & 433 & 0.69 & 1.03 \\
\hline P 735 & 35 & 173.2 & 346 & 520 & 433 & 650 & 1.03 & 1.55 \\
\hline O 1010 & 35 & 178.5 & 357 & 536 & 446 & 670 & 1.06 & 1.59 \\
\hline P 1010 & 35 & 267.8 & 536 & 804 & 670 & 1005 & 1.60 & 2.39 \\
\hline O 77 & 35 & 221.0 & 441 & 663 & 552 & 829 & 1.32 & 1.97 \\
\hline P 77 & 35 & 331.5 & 663 & 994 & 829 & 1243 & 1.97 & 2.96 \\
\hline
\end{tabular}

Note. $\mathrm{O}=$ optimistic assumptions. $\mathrm{P}=$ pessimistic assumptions. The assumed capital costs in tropical countries range from US $\$ 1,500$ to $\$ 2,250$ per ha and in temperate countries from US\$3,000 to $\$ 4,500$. $25 \%$ has been added to these costs to cover other forestry operations. It is assumed that planting takes place over a period of 10 years, except for the 7 year rotations, which take place over a period of 14 years. Detailed calculations are given in Annex 2

for the period 2022-2050 and the annual capture of carbon and removals from 2050 onwards.

From Table 1, under the assumed models, the minimum area of plantations required to capture $420 \mathrm{GtC}$ by 2050 is 109 million ha, of which 72.67 million ha will be in tropical countries and 36.33 million ha will be in temperate countries. One-third of the area is on a rotation of 10 years and two-thirds on a 35 year rotation. However, this gives the least amount of removals 70,520 million $\mathrm{m}^{3}$ over the period 2026 to 2050 , which amounts to $647 \mathrm{~m}^{3} / \mathrm{ha}$.

Meanwhile, under the above assumptions, the largest area required is 331.5 million ha, with two-thirds of the area on a rotation of 7 years and one-third on a 35 year rotation. This gives the largest volume of removals 164,570 million $\mathrm{m}^{3}$, but only $496 \mathrm{~m}^{3} / \mathrm{ha}$. However, the optimistic alternative would give $744 \mathrm{~m}^{3} / \mathrm{ha}$.

After 2050, the annual capture of atmospheric carbon ranges from 14.74 to $15.32 \mathrm{GtC}$. This is more than the projected emissions from fossil fuels (12 GtC) so the amount of $\mathrm{CO}_{2}$ in the atmosphere could start to decline, especially if there is a concerted effort to substitute renewable energy for fossil fuels and energy efficiency measures have increased. After 2050, the energy value from the wood removals ranges from 38 to $76 \mathrm{EJ}$ : this is $8 \%$ to $17 \%$ of the projected energy value from burning fossil fuels (450 EJ). Together with wood from existing forest areas, renewable wood energy could replace a significant part of fossil fuel use, bearing in mind the conversion efficiency losses when producing more convenient forms of energy (Openshaw 2011).

From the author's field experience and a book on cost and financial accounting in forestry (Openshaw 1980), the capital and maintenance costs for tropical tree species are between US\$1,500 and $\$ 2,250$ per ha. It is assumed that the short-rotation species may not have to be replanted for five rotations as they regenerate from suckers. At each sucker rotation, excess stem shoots have to be thinned until only the best one or two are left to grow (singling). These operations will add an estimated $25 \%$ to the capital/management costs. The tropical species on a 35 year rotation will have similar planting and management costs. Thinnings will start at year 10 and be at intervals of 5 years, with the final felling at year 35 . An additional $25 \%$ has been added to the costs to cover these operations.

For temperate species, the capital cost is estimated at $\$ 3,000$ to $\$ 4,500 / \mathrm{ha}$, including overheads and additional work. It is assumed that these species will be on a 35 year rotation, with the first thinning at year 10 and then at intervals of 5 years until the final felling at age 35 years. These operations are assumed to add $25 \%$ to the establishment and management costs. Table 2 gives the estimated capital and total costs for the models given in Table 1 to sequestrate $420 \mathrm{Gt}$ of atmospheric carbon by 2050, (1,540 $\mathrm{GtCO}_{2}$ equivalent).

Of course, the value of land has not been taken into consideration; suitable land in the tropics may be valued at US\$500-1,000/ha (FAO 2000). But it may be owned by the government or by private individuals who plan to plant trees on the area. Similarly, suitable land in temperate areas may be valued at US\$5,000-30,000/ha (FAO 2000). But in order to reclaim land or gainfully use setaside land, tree planting may be the best option. However, on average, if land prices are taken into consideration, this would increase the cost of carbon sequestration by US $\$ 1.86$ to 5.99 per tC (US\$0.51 to 1.63 per $\mathrm{tCO}_{2}$ equivalent). This is an additional US\$1.64 per tC in tropical areas and US $\$ 5.00$ per tC in temperate areas, assuming that average land prices in tropical and temperate areas are US\$750 and US\$17,500 per ha, respectively. This proposal and the various models should be a key candidate for the US $\$ 100$ billion per year that is targeted for the 'green carbon fund'.

However, because the plantations will be managed and provide wood products, not all the carbon will be 
Table 3. 2010 Global land area by land use types and population forecasts for 2015 \& 2050 .

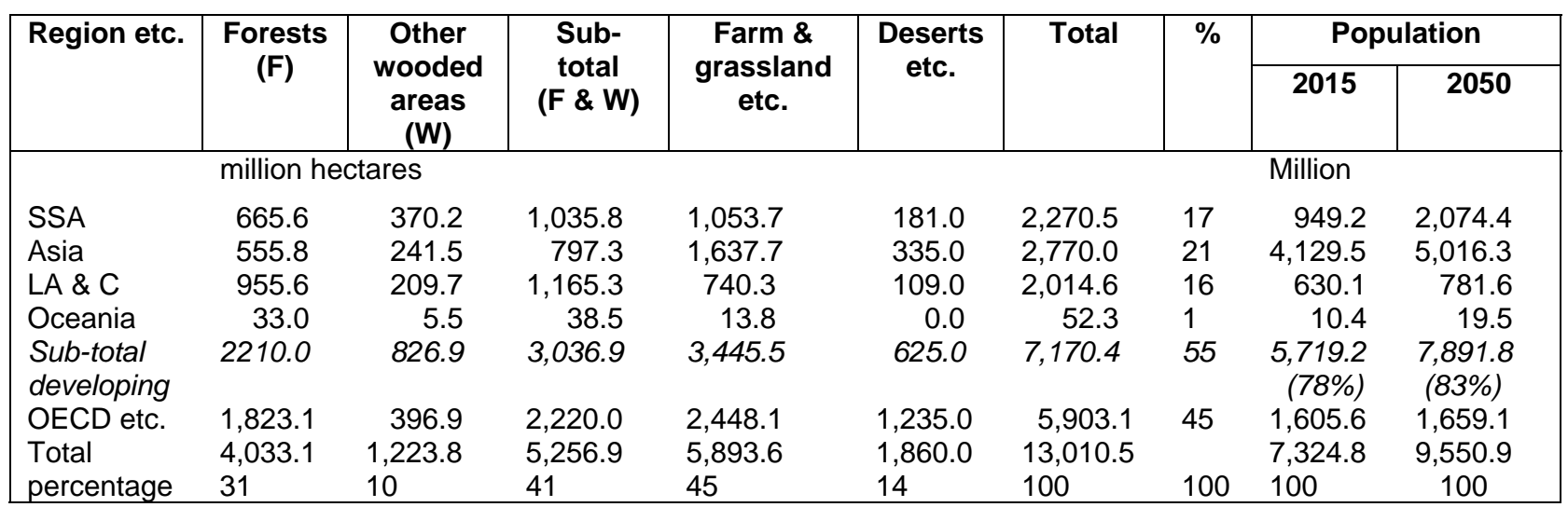

Note. SSA = sub-Saharan Africa, including Sudan. LA\&C: The Caribbean, Mexico, Central \& Southern America. The sub-total is for all developing countries. OECD includes: all countries in the OECD except Chile, Mexico and Turkey; North African countries, except Sudan; Gulf oil states; Cyprus, Lebanon, Hong Kong, Macau, Singapore, Taiwan and New Caledonia.

Source. 2010b. Global forest resource assessment, FAO FP 163. FAO 2009 State of the World's Forests. Population forecasts from Population Pyramid 2012<populationpyramid.net>. 2010 population was $6,852.5 \mathrm{~m}$. of which 5,222.5 m. was in LDCs.

stored in the standing trees. Therefore, the cost of sequestrating carbon should be lower than stated above. Removals will occur from year 7 for some tropical species and year 10 for the other species. Of course, this is only for the chosen models; there may be variations ranging from rotations of 2 years to rotations of 50 years with differing yields and costs. But the chosen rotations are used as examples of what could be achieved. After 2050, when the areas are in 'normal' rotations, the 'tropical tree crop' will yield $37.5 \mathrm{~m}^{3}(22 \mathrm{t}$ ) of above-ground wood per ha per year and the temperate crop will yield $18.75 \mathrm{~m}^{3}$ $(11 \mathrm{t})$ of above-ground wood per ha per year. In the chosen models, this amounts to between of 2,720 and 5,520 million $\mathrm{m}^{3}$ (Table 1). Besides storing carbon in wood and soils, the plantations provide traditional wood products - sawnwood, panel products and paper, including bio-energy. The latter includes: solid (fuelwood, wood pellets/densified wood, charcoal); liquid, (methanol [wood alcohol], ethanol and other liquid energy/chemical forms); and gaseous, (producer gas/gen gas). Plantations can also provide other products such as eucalyptus oil, resin and rosin, wood ash fertilizer, and non-timber forest products (NTFPs) such as fruit, mushrooms and medicines, thus enhancing the economic potential for rural people.

\section{Farmland and Grassland: Plantation Area requirements for CCS with the above Models}

Will there be sufficient areas of farmland and grassland, to meet the proposed plantation areas, which range from a minimum of 109 million ha to a maximum of 331.5 million ha, assuming that these areas come from outside the forest? Table 3 gives a breakdown of land use types for broad regions of the world. The area of farmland and grassland in developing countries is $3,445.5$ million ha.
The proposed area of plantations in the tropics for CCS ranges from 72.7 to 221 million ha. If all the proposed plantations come from these lands, they represent $2.1 \%$ to $6.4 \%$ of total area. Of course some land could come from degraded forests, so the actual total from tropical farmland etc. may be $2 \%$ to $6 \%$ (69 to 207 million ha).

In temperate areas, the area of farmland etc. required for CCS ranges from 36.3 to 110.5 million ha $(1.5 \%$ to $4.5 \%)$ and if degraded forests were part of the CCS, then the farmland area etc. may be $1.4 \%$ to $4.25 \%$ of the total (35 to 104 million ha). There are considerable areas of farmland, both rainfed and irrigated, that have been abandoned due to land exhaustion, falling yields, salination and invasion by weeds, pest and diseases such as witchweed (Striga asiatica), congon grass (Imperata cylindrica), black bean aphids, stem borer moth etc. (CABI 2011). Top priority should be given to the reclamation of such abandoned areas and to reducing pests and diseases. These areas are candidates for tree plantations, but some reclamation costs may be high.

There are many tree species that can be used to reclaim land, ranging from low to high rainfall areas and from saline to calciferous soils. NAS (1979) lists tree and other legumes that can be used to restore lands from deserts to tropical highlands. For example, Prosopis spp., including mesquite, can be used to reclaim dry areas, but the total carbon accumulation may only be in the range of 3 to $5 \mathrm{tC} / \mathrm{yr}$. Mesquite is sometimes regarded as a weed species, because animals, especially ruminants, eat the leaves and the seed pods. However, they cannot digest the seed, which is then passed out with the dung. This generally regenerates and spreads. However, if the seed pods are collected and milled, thus destroying the seed, the resulting product can and is sold as an excellent animal feed. All legumes, especially tropical tree legumes, have a critical role to play in land reclamation and improving agricultural productivity. Other NAS books 
of note are: Firewood Crops (NAS 1980) and Firewood Crops, Volume 2, (NAS 1983).

\section{Increasing Arable and Pastoral Productivity}

The main causes of deforestation are clearing land for subsistence agriculture, including shifting cultivation, due to population pressure and the increased demand for cash crops, not harvesting wood as is often cited, (Openshaw 2011). Can this clearing be slowed down and eventually reversed? Can agricultural productivity increase by at least the rate of population increase? This will now be discussed.

The usual methods to increase agricultural productivity are: applying increased amounts of artificial fertilizers, which are produced using fossil fuels; crop and animal breeding, including genetically modified crops; and applying pesticides and herbicides. However, there are other ways to increase productivity using 'natural' methods. Planting shelterbelts reduces evapotranspiration of cash crops to increase yields. These are used in several countries from China to Egypt. Intercropping with nitrogen-fixing species including nitrogen-fixing tree species can at least stabilize agricultural productivity, if not improve it (Beets 1985). Also nitrogen-fixing tree species can be used to intercrop in place of shifting cultivation and to eliminate the invasive grass species Imperata cylindrical, (ICRAF 1999). Brassicas (cabbage etc.) and beans planted side by side can deter the black bean aphid (Aphis fabae) from attacking the cabbage. This lesson was applied to maize in East Africa. Scientists from Rothamstead agricultural research facility (UK) found that planting napier grass (Pennisetum purpureum) round the edges of maize fields and intercropping the maize with molasses grass (Melinis minutiflora), deterred the stem borer moths (Busseola fusca and Cholo partellus). These grasses also attracted parasitic wasps that prey on the stem borer moths. Not only were maize (and sorghum) yields increase, but the two grasses are edible fodder for cattle, which meant that farmers can increase their animal stock and provide more milk and dung to fertilise the fields, (The Guardian Weekly, 2003) The grasses also increase the amount of carbon stored in their roots and the soil. Again, one of the curses of poor farmers on poor land in Africa (and elsewhere) is witchweed (Striga asiatica), (CABI 2011), which parasitizes the roots of cereal crops and kills them. The striga seeds can lay dormant for many years and are difficult to control. The same scientists found that a tree legume Desmodium uncinatum or silverleaf if intercropped with maize resulted in no striga invasion although adjacent maize fields without silverleaf were nearly devastated by it. This has more than doubled the yield of maize and the silverleaf provides cattle fodder and stick wood, (The Guardian Weekly, 2003). These are but some examples of the symbiotic relationship between plants that can be easily adapted by farmers, especially subsistence ones to increase their plant and animal yields. Many (tropical) soils are acidic and because of this, the uptake of minerals such as potassium $(K)$ \& phosphorous $(P)$ may be curtailed. The controlled application of lime (calcium hydroxide) can make the soils alkaline or reduce their acidity, thus facilitating mineral uptake by plants. This is a simple and effective way to increase productivity!

One of the problems of global warming is that increased temperatures, especially at night, may inhibit the flowers of cereal crops from setting. Rice is the chief crop in many parts of the world, especially in Asia. Scientists at the International Rice Research Institute (IRRI) in the Philippines have a breeding programme to develop rice strains that can tolerate increased night-time temperatures without affecting rice yields, (personal visit). This is but one example of a necessary response to the negative effects of global warming.

Shifting cultivation is a method whereby farmers can grow crops for two or three years on cleared forest areas, before the crop yields are too low for sustenance. The farmers then move to new forest areas and repeat the process, allowing former cleared lands to recover for about 20 years before the cycle is repeated. However, because of increase population pressures, the recovery cycle in many cases is shortened and the cropping time is also curtailed, resulting in smaller sustained crop yields and shorter recovery time. Inter-planting nitrogen-fixing crops, especially tree species, can stabilize agricultural productivity and provide animal browse and/or mulch to the soil as well as stick wood. Also, wood ash is a good fertilizer, being relatively rich in $\mathrm{K}$, a critical ingredient to maintain soil fertility along with nitrogen $(\mathrm{N})$ and $\mathrm{P}$.

\section{Population Pressure on Natural Resources, especially Forests}

The present day World population is over 7 billion (Table 3) and by 2050 it is forecast to grow to over 9.5 billion if nothing is done to temper population increase. Most of the increase will be in LDCs, which by then may house $78 \%$ of the population on $55 \%$ of the land area. By 2100 , the world's population could reach 10.85 billion. SubSaharan Africa's population is estimated to more than double by 2050 to over 2 billion and may reach 3.82 billion by 2100, (Population Pyramid 2012). Therefore, for the sake of the planet and Homo sapiens in particular, a concerted effort should be made to temper population increase.

The author lived in Tanzania in the late 1960s and in Thailand in the early 1970s undertaking wood consumption surveys/timber trend studies for the Food and Agricultural Organization (FAO). From that time, Thailand pursued a vigorous family planning policy, whereas in Tanzania, little effort was made in the field of 
Table 4. Population and GDP growth from 1970 to 2013 in Tanzania and Thailand.

\begin{tabular}{|c|c|c|c|c|c|c|c|c|}
\hline Year & TZ & TH & TZ & TH & TZ & TH & TZ & TH \\
\hline & \multicolumn{2}{|c|}{ Population growth rate } & \multicolumn{2}{|c|}{ Population } & \multicolumn{2}{|l|}{ GDP } & \multicolumn{2}{|c|}{ GDP per capita } \\
\hline & \multicolumn{2}{|c|}{$\%$ per year } & \multicolumn{2}{|c|}{ million } & \multicolumn{2}{|c|}{ US\$ $\$ 10^{9}$} & \multicolumn{2}{|c|}{ US\$ } \\
\hline 1970 & 3.1 & 2.9 & 13.60 & 36.88 & 1.90 & 7.09 & 140 & 192 \\
\hline 2013 & 3.0 & 0.3 & 49.25 & 67.01 & 33.20 & 387.30 & 674 & 5,780 \\
\hline
\end{tabular}

Note. $\mathrm{TZ}=$ Tanzania. $\mathrm{TH}=$ Thailand. Land area of $\mathrm{TZ}=94.5$ million ha. $\mathrm{TH}=51.3$ million ha. Purchasing Power Parity in 2013 : $\mathrm{TZ}$. $\$ 1,700$. TH, $\$ 13,430$. GDP = Gross Domestic Production. Source. Google search. Other factors that may influence population growth rates are education and existing infrastructure etc.

family planning. Table 4 examines population growth and increase in gross domestic production from 1970 to 2013 in both countries. It illustrates the contrast between these two countries.

In 1970, Tanzania had only $37 \%$ of Thailand's population, but by 2013 , the Tanzanian population was $73 \%$ that of Thailand and by 2024 , the populations may be on par. By 2100, the population of Tanzania could be over 275 million, whereas that of Thailand is forecast to shrink to 40.5 million, (population pyramid 2012).

Because of the slower increase in population in Thailand, more money was put into productive activities and expanding infrastructure such as (rural) electrification and road building: farmers were also given more subsidies. In contrast, Tanzania had to devote more resources to schools and hospitals etc. Thus, its percapita GDP only increased 4.8 times, where as that of Thailand increase 30 times from 1970 to 2013! Thailand has only $54 \%$ of the land area compared to Tanzania, but most of the land is far more productive and its average annual rainfall is over $1,500 \mathrm{~mm}$. In contrast the average annual rainfall in most parts of Tanzania is under 1,000 $\mathrm{mm}$. It is difficult to see how Tanzania can meet the future food and other natural resource requirements of its population without a vigorous family planning policy like that of Thailand.

In sub-Saharan Africa, Tanzania is not an exception when it comes to promoting family planning. This is why SSAs population is forecast to more than double by 2050 . Also, there are many other LDCs whose population is expanding rapidly such as those in the Indian subcontinent, Brazil, Indonesia and the Philippines. Education, especially for girls is a key area to promote family planning. Family planning should be part of the school curriculum with easy access to free or cheap birthcontrol devices such as condoms. In some countries, the World Food Programme (WFP) provides tins of cooking oil if parents send their daughters to school. Such an initiative should be expanded. Health workers (bare-foot doctors) should pay many visits to rural areas to promote family planning. Local women of stature should be trained, equipped and paid to encourage youths and adults of child-bearing age to practice birth control.

Job opportunities, especially for women should be expanded. The above CCS proposal is an excellent way to expand employment opportunities. Rural people, especially women could start tree nurseries, plant and manage trees, have stove-building enterprises, and expand the collection, manufacture and sale of wood and non-timber forest products. Plots should be established to demonstrate agro-forestry methods and free seeds, especially of appropriate nitrogen-fixing species should be made available. All rural schools should have tree nurseries and children should be taught environmental awareness etc. In other words, much more effort and money must be provided to promote family planning as in Thailand. Such 'population' and 'agricultural initiatives' may require an amount of money equal to or more than the above proposed budget for CCS, but without these programmes, the slowing down of deforestation, even with such programmes as Reduced Emissions from Deforestation and Forest Degradation (REDD+), may be fighting a losing battle. Those in authority should trust the (rural) people and take them into their confidence. Bureaucracy must be reduced to a minimum. Plantation areas can be checked by satellite, with some ground truthing. It is proposed that rural people willing to plant and manage trees, especially in the tropics should be paid the above amount of money on a per-ha basis and once the carbon is fully captured in the wood and forest soils an additional amount of money could be paid from the 'green carbon fund'. Money for planting and management should be handed directly to the people or through trusted Chiefs and NGOs etc. This should assist many people, especially the rural poor in developing nations, and be an essential part in the quest for GHG mitigation and truly sustainable development.

\section{REFERENCES}

Barnham Keith(2014). The burning answer: a user's guide to the solar revolution. Weidenfield \& Nicolson, 5 Upper Saint Martin's Lane, London, WC2H 9EA. www.orionbooks.co.uk

Beets WC(1985). Agroforestry in African farming systems. Energy in Africa Series. E/DI (Now Engility Corporation [IRG]), $101518^{\mathrm{th}} \mathrm{St}$. N.W. Suite 802, Washington, D.C. 20036.

Berners-Lee $M$, Clark $D(2013)$. The burning question. Profile Books Ltd., 3a Exmouth House, Pine St., London EC1R 0JH. www.profinebooks.com

Bryant Steven L(2013). The one-stop carbon solution. Scientific American, November 2013. Volume 309 \# 5. Pp 75-77. Scientific American, a division of Nature America Inc. 75 Varic St. $9^{\text {th }}$ Floor, New York N.Y. 10013-1917. www.scientificAmerica.com

$\mathrm{CABI}(2011)$. Invasive species compendium: Imperata cylindrical. Commonwealth Agricultural Bureau International Publishing. 2011. www.cabi.org/ISC. 
$\mathrm{FAO}(2000)$. The global outlook for future wood supply from forest plantations. Working paper \# GFPOS/WP/03. The Food and Agricultural Organization of the UN (FAO), Rome, Italy.

FAO(2009). State of the World's forests. The Food and Agricultural Organization of the UN (FAO), Rome, Italy.

FAO(2010a). What woodfuel can do to mitigate climate change? Forestry Paper 162. The Food and Agricultural Organization of the UN (FAO), Rome, Italy.

FAO (2010b). Global forest resource assessment. Forestry Paper 163. The Food and Agricultural Organization of the UN (FAO), Rome, Italy.

Hall DO, Rao KK(1994). Photosynthesis: fifth edition. Cambridge University Press. The Pitt Building, Trumpington Street, Cambridge CB2 1RP, England, U.K.

10. The Economist 2014. Climate diplomacy: flexible or toothless? Pp $72 / 73$. Volume $413, \# 8916,6^{\text {th }}$ Dec. 2014. London, U.K.

ICRAF (1999). Imperata grasslands rehabilitation using agroforestry and assisting natural regeneration. International Centre for Research into Agroforestry, Bogor, Indonesia.

International Energy Agency. 2014. World energy outlook 2014. IEA, Paris, France.

Intergovernment Panel on Climate Change. 2014. Fifth assessment report (AR5) - climate change. IPPC Secretariat C/O WMO, 7bis Avenue de la Paix. C.P. $2300 \mathrm{CH}-1211$, Geneva, Switzerland.

The Guardian Weekly. 2003. Perfect maize in three simple steps. $16^{\text {th }}$ October 2003. The GNM Ltd, Centurion House, 129 Deansgate, Manchester M3 3WR, U.K.

The Guardian Weekly. 2015. Climate change inaction pushes on 'Doomsday Clock.' $30^{\text {th }}$ January 2015. The GNM Ltd, Centurion House, 129 Deansgate, Manchester M3 3WR, U.K.
NAS(1979). (National Academy of Sciences) Tropical legumes: resources for the future. NAS, 2101 Constitutional Avenue, Washington, D.C. 20418, USA.

NAS (1980). Firewood crops: shrub and tree species for energy production. NAS, 2101 Constitutional Avenue, Washington, D.C. 20418, USA.

NAS (1983). Firewood crops: Volume 2: shrub and tree species for energy production. NAS, 2101 Constitutional Avenue, Washington, D.C. 20418 , USA.

Openshaw K(1980). Cost and financial accounting in forestry: a practical manual. Pergamon Press, Ltd. Headington Hill Hall, Oxford OX3 OBW, England, UK.

Openshaw K(2011).Supply of woody biomass, especially in the tropics: is demand outstripping supply? The International Forestry Review. Vol. 13 (4) 2011, The Crib, Dinchope, Craven Arms, Shropshire SY7 9JJ, England.

Pan Y, Birdsey RA, Phillips OL, Jackson RB (2013).The structure, distribution and biomass of the World's forests. Northern Research Station, 11 Campus Blvd, Suite 200, Newtown Sq. PA 19073, USA. \& Annual Review of Ecology, Evolution and Systematics. 2013: 44 p593-622.

Population Pyramid. 2012. <populationpyramid.net>

Silver W, Ostertag R, Lugo $A(2000)$. The potential for carbon sequestration through reforestation of abandoned tropical agricultural land. Restoration Ecology.Vol. 8(4) $394-407$ 


\section{Annex 1.}

The method used to calculate the area of plantations required to capture $420 \mathrm{Gt}$ of atmospheric carbon over a period of 35 years, with three plantations of different rotation ages in tropical regions (7,10 and 35 years) and one in temperate regions (35 years) is given below. It is assumed that two-thirds of the planting will take place in the tropics and one-third in temperate regions. The planting is to be phased over 10 years, except for the 7-year rotation which will be phased over 14 years. In tropical areas, two average annual stem growth rates have been assumed, namely $30 \mathrm{~m}^{3} / \mathrm{ha}^{3}$ (optimistic - O) and $20 \mathrm{~m}^{3} / \mathrm{ha}$ (pessimistic $-\mathrm{P}$ ). In temperate areas the assumed annual stem growth rates are $15 \mathrm{~m}^{3} / \mathrm{ha}^{2}$ (O) and $10 \mathrm{~m}^{3} / \mathrm{ha}(\mathrm{P})$.

Table A1. Average stem volume increment in $\mathrm{m}^{3}$ of 1 hectare planted each year for 10 years and thereafter from 11 to 35 years on a 10-year rotation assuming average annual growth rate of $30 \mathrm{~m}^{3} / \mathrm{ha}$.

\begin{tabular}{|l|l|l|l|l|l|l|l|l|l|l|l|l|l|}
\hline Year & 1 & 2 & 3 & 4 & 5 & 6 & 7 & 8 & 9 & 10 & $11-35$ & $\begin{array}{l}\text { Sum 1-35 } \\
\text { for 10 ha. }\end{array}$ & $\begin{array}{l}\text { Sum ha } \\
\text { ha }\end{array}$ \\
\hline $\begin{array}{l}\text { Stem } \\
\text { vol. }\end{array}$ & 30 & 90 & 180 & 300 & 450 & 630 & 840 & 1,080 & 1,350 & 1,650 & $\begin{array}{l}1,650 \text { per } \\
\text { yr. }\end{array}$ & 47,850 & 4,785 \\
\hline
\end{tabular}

Note. It is assumed that one ha is planted each year for 10 years. From 10 years onwards there is a constant growth of $165 \mathrm{~m}^{3} / \mathrm{ha}$. This accumulates over time to give a total of $4,785 \mathrm{~m}^{3} / \mathrm{ha}$ of stem wood. This is gross volume. Net volume takes into account removals. See below.

Table A2. The gross and net amount of above and below-ground wood and soil carbon produced by three different rotations in the tropics and one in temperate regions for 35 years, together with the wood removals over the same time period.

\begin{tabular}{|c|c|c|c|c|c|c|c|c|c|}
\hline \multirow{2}{*}{\multicolumn{2}{|c|}{$\begin{array}{l}\text { Rotation age } \\
\text { Annual stem growth }\end{array}$}} & \multicolumn{2}{|c|}{10 years: tropics } & \multicolumn{2}{|c|}{7 years: tropics } & \multicolumn{2}{|c|}{35 years: tropics } & \multicolumn{2}{|c|}{35 years: temperate } \\
\hline & & $30 \mathrm{~m}^{3} / \mathrm{h}$ & & $30 \mathrm{~m}^{3} / \mathrm{h}$ & & $30 \mathrm{~m}^{3} / \mathrm{ha}$ & & $15 \mathrm{~m}^{3} / \mathrm{h}$ & \\
\hline Item & unit & Capital & removals & capital & Removals & capital & removals & capital & removals \\
\hline Stem wood & $\mathrm{m}^{3}$ & 4,785 & 780 & 3,300 & 765 & 14,525 & 515 & 7,262 & 258 \\
\hline $\begin{array}{l}\text { Stem } \\
\text { branch }\end{array}$ & $\mathrm{m}^{3}$ & 5,981 & 975 & 4,125 & 956 & 18,156 & 644 & 9,078 & 322 \\
\hline $\begin{array}{lll}\text { St+ } & \mathrm{Br} & + \\
\text { Root } & & \end{array}$ & $\mathrm{m}^{3}$ & 7,476 & - & 5,156 & - & 22,695 & - & 11,348 & - \\
\hline$S+B+R$ & tonne & 4,398 & 574 & 2,033 & 562 & 13,350 & 379 & 6,675 & 189 \\
\hline$S+B+R$ & $\mathrm{tC}$ & 2,177 & 284 & 1,501 & 278 & 6,608 & 187 & 3,304 & 94 \\
\hline Removals & $\mathrm{tC}$ & 284 & & 278 & & 187 & & 94 & \\
\hline Net weight & $\mathrm{tC}$ & 1,893 & & 1,223 & & 6,421 & & 3,210 & \\
\hline Soil Carbon & $\mathrm{tC}$ & 25 & & 23 & & 25 & & 13 & \\
\hline Total for 35yr & $\mathrm{tC}$ & 1,918 & & 1,246 & & 6,446 & & 3,223 & \\
\hline
\end{tabular}

Note. Assumed that: branch wood is $20 \%$ of above-ground volume; roots are $20 \%$ of total volume; 1 t dry wood = $1.7 \mathrm{~m}^{3}$; ash content of wood $=1 \%$; carbon content of ash-free wood $=50 \%$. Annual accumulation of soil: $\mathrm{C} / \mathrm{ha}$ $0.82 \mathrm{t}$ tropics, $0.41 \mathrm{t}$ temperate. The average amount of carbon sequester per ha is one-third of each rotation age, e.g. $1918+6446+3223=11,587 / 3=3862 \mathrm{tC}$. This is then divided into $420 \mathrm{GtC}$ to obtain the plantation area. For 10: 35 : 35 rotations $=109$ million ha. For removals, it is in $\mathrm{m}^{3}, 975+644+322=1941 / 3=647$. This is then multiplied by the plantation are of 109 million ha to give 70.52 mil. $\mathrm{m}^{3}$. 
Table A3. The yearly average annual per-hectare gross and net amount of total wood and soil carbon produced by the four different rotations, together with the wood removals.

\begin{tabular}{|c|c|c|c|c|c|c|c|c|c|}
\hline \multicolumn{2}{|l|}{ Rotation age } & \multicolumn{2}{|c|}{10 years: tropics } & \multicolumn{2}{|c|}{7 years: tropics } & \multicolumn{2}{|c|}{35 years: tropics } & \multicolumn{2}{|c|}{35 years: temperate } \\
\hline Annual stem & owth & $30 \mathrm{~m}^{3} / \mathrm{ha}$ & & $30 \mathrm{~m}^{3} / \mathrm{ha}$ & & $30 \mathrm{~m}^{3} / \mathrm{ha}$ & & $15 \mathrm{~m}^{3} / \mathrm{ha}$ & \\
\hline Item & unit & Capture & removals & capture & Removals & Capture & removals & capture & removals \\
\hline Stem wood & $\mathrm{m}^{3}$ & 165.00 & 30.00 & 120.00 & 30.00 & 540.00 & 30.00 & 270.00 & 15.00 \\
\hline $\begin{array}{l}\text { Stem } \\
\text { branch }\end{array}$ & $\mathrm{m}^{3}$ & 206.25 & 37.50 & 150.00 & 37.50 & 675.00 & 37.50 & 337.50 & 18.75 \\
\hline $\begin{array}{lll}\mathrm{St}+ & \mathrm{Br} & + \\
\text { Root } & & \\
\end{array}$ & $\mathrm{m}^{3}$ & 257.81 & - & 187.50 & - & 843.75 & - & 421.88 & - \\
\hline$S+B+R$ & tonne & 151.65 & 22.06 & 110.29 & 22.06 & 496.32 & 22.06 & 248.16 & 11.03 \\
\hline$S+B+R$ & tC & 75.07 & 10.92 & 54.60 & 10.92 & 245.68 & 10.92 & 122.84 & 5.46 \\
\hline Removals & tC & 10.92 & & 10.92 & & 10.92 & & 5.46 & \\
\hline Net weight & tC & $\begin{array}{ll}0.05 \\
64.15\end{array}$ & & 43.68 & & 234.76 & & 117.38 & \\
\hline Soil Carbon & $\mathrm{tC}$ & 0.82 & & 0.82 & & 0.82 & & 0.41 & \\
\hline Total for 35yr & $\mathrm{tC}$ & 64.97 & & 44.50 & & 235.58 & & 117.79 & \\
\hline
\end{tabular}

Note. Assumed that: branch wood is $20 \%$ of above-ground volume; roots are $20 \%$ of total volume; $1 \mathrm{t}$ dry wood $=1.7 \mathrm{~m}^{3}$; ash content of wood $=1 \%$; carbon content of ash-free wood $=50 \%$. Annual accumulation of soil C/ha, $0.82 \mathrm{t}$ tropics, $0.41 \mathrm{t}$ temperate. Calculation as above, e.g. for 10:35:35 rotations $-64.97+235.58+117.79=418.34 / 3=139.45$ tC. Thus, carbon sequestrated each year $=109$ million ha $\times 139.45 \mathrm{tC}=15.20 \mathrm{GtC}$.

\section{Annex 2}

Table A4. Total cost build-up for the different rotations in tropical and temperate countries for the models as specified in Table 1, assuming a total per ha cost of $\$ 1,875$ in tropical and $\$ 3750$ in temperate areas.

\begin{tabular}{|c|c|c|c|c|c|c|}
\hline \multicolumn{2}{|c|}{ Rotation period } & \multirow{2}{*}{$\begin{array}{l}\text { Area planted } \\
\text { for } \\
\text { rotation }\end{array}$} & \multicolumn{3}{|c|}{ Total cost for each rotation choice } & \multirow{2}{*}{$\begin{array}{l}\text { Total cost } \\
\text { All areas }\end{array}$} \\
\hline $\begin{array}{l}\text { Tropical } \\
\text { plantations }\end{array}$ & $\begin{array}{l}\text { Temperate } \\
\text { plantations }\end{array}$ & & $\begin{array}{l}\text { Tropical } \\
\text { rotat'n } 10 \text { or7 } \\
\text { yr. }\end{array}$ & $\begin{array}{l}\text { Tropical } \\
\text { rotation } \\
\text { yr. }\end{array}$ & $\begin{array}{l}\text { Temperate } \\
\text { rotation }-35 \\
\text { yr. }\end{array}$ & \\
\hline Years & years & million ha & $\$$ million & $\$$ million & $\$$ million & $\$$ million \\
\hline $0 \quad 10 \quad 35$ & 35 & 36.333 & 68,125 & 68,125 & 136,250 & 272,500 \\
\hline $\begin{array}{lll}P & 10 & 35 \\
\end{array}$ & 35 & 54.500 & 102,185 & 102,185 & 204,375 & 408,750 \\
\hline $\begin{array}{lll} & 7 & 35 \\
\end{array}$ & 35 & 38.500 & 72,185 & 72,185 & 144,375 & 288,750 \\
\hline $\begin{array}{lll}P & 7 & 35 \\
\end{array}$ & 35 & 57.733 & 108,250 & 108,250 & 216,500 & 433,000 \\
\hline $\begin{array}{lll} & 10 & 10 \\
\end{array}$ & 35 & 59.533 & 111,625 & 111,625 & 223,250 & 446,500 \\
\hline $\begin{array}{lll}P & 10 & 10 \\
\end{array}$ & 35 & 89.333 & 167,500 & 167,500 & 335,000 & 670,000 \\
\hline 07 & 35 & 73.667 & 138,125 & 138,125 & 276,250 & 552,500 \\
\hline P 7 & 35 & 110.500 & 207,190 & 207,190 & 414,375 & 828,750 \\
\hline
\end{tabular}

Note. $\mathrm{O}=$ optimistic assumptions. $\mathrm{P}=$ pessimistic assumptions. The assumed capital costs in tropical countries range from US $\$ 1,500$ to $\$ 2,250$ per ha and in temperate countries from US $\$ 3,000$ to $\$ 4,500$. In addition, $25 \%$ has been added to these costs to cover other operations. It is assumed that planting takes place over a period of 10 years, except for the 7 year rotations, which take place over a period of 14 years. 
Table A5. Total cost build-up for the different rotations in tropical and temperate countries for the models as specified in Table 1 , assuming a total per ha cost of $\$ 2,812.5$ in tropical and $\$ 5,625$ in temperate areas.

\begin{tabular}{|c|c|c|c|c|c|c|}
\hline \multicolumn{2}{|c|}{ Rotation period } & \multirow{2}{*}{$\begin{array}{l}\text { Area planted } \\
\text { for } \\
\text { rotation }\end{array}$} & \multicolumn{3}{|c|}{ Total cost for each rotation choice } & \multirow{2}{*}{$\begin{array}{l}\text { Total cost } \\
\text { All areas }\end{array}$} \\
\hline $\begin{array}{l}\text { Tropical } \\
\text { plantations }\end{array}$ & $\begin{array}{l}\text { Temperate } \\
\text { plantations }\end{array}$ & & $\begin{array}{l}\text { Tropical } \\
\text { rotat'n } 10 \text { or7 } \\
\text { yr. }\end{array}$ & $\begin{array}{l}\text { Tropical } \\
\text { rotation } \quad-35 \\
\text { yr. }\end{array}$ & $\begin{array}{l}\text { Temperate } \\
\text { rotation } \quad-35 \\
\text { yr. }\end{array}$ & \\
\hline Years & years & million ha & $\$$ million & \$ million & $\$$ million & $\$$ million \\
\hline $0 \quad 1035$ & 35 & 36.333 & 102,185 & 102,185 & 204,375 & 408,745 \\
\hline $\mathrm{P} \quad 10 \quad 35$ & 35 & 54.500 & 153,280 & 153,280 & 306,565 & 613,125 \\
\hline $0 \quad 7 \quad 35$ & 35 & 38.500 & 108,280 & 108,280 & 216,565 & 433,125 \\
\hline $\begin{array}{lll} & 7 & 35 \\
\end{array}$ & 35 & 57.733 & 162,375 & 162,375 & 324,750 & 649,500 \\
\hline $0 \quad 1010$ & 35 & 59.533 & 167,435 & 167,435 & 334,875 & 669,750 \\
\hline $\begin{array}{lll}\mathrm{P} & 10 & 10\end{array}$ & 35 & 89.333 & 251,250 & 251,250 & 502,500 & $1,005,000$ \\
\hline $\begin{array}{lll}\mathrm{O} & 7 & 7 \\
\end{array}$ & 35 & 73.667 & 207,190 & 207,190 & 414,375 & 828,750 \\
\hline $\mathrm{P} 7$ & 35 & 110.500 & 310,780 & 310,780 & 621,000 & $1,243,125$ \\
\hline
\end{tabular}

Note. $\mathrm{O}=$ optimistic assumptions. $\mathrm{P}=$ pessimistic assumptions. The assumed capital costs in tropical countries range from US $\$ 1,500$ to $\$ 2,250$ per ha and in temperate countries from US $\$ 3,000$ to $\$ 4,500$. In addition, $25 \%$ has been added to these costs to cover other operations. It is assumed that planting takes place over a period of 10 years, except for the 7 year rotations, which take place over a period of 14 years. These assumed costs may be on the high side.

To obtain a cost per tonne of sequestrated carbon, the total costs are divided by $420 \mathrm{GtC}$,

For example: US $\$ 272.5 \times 109$ divided by 420 tC $\times 109=$ US $\$ 0.65$ per tC, or $\$ 0.18$ per tCO $\mathrm{CO}_{2}$.To obtain the cost per tCO multiply by 12 and divide by 44 . 